\title{
Reflektioner om dilemman i social barnavård
}

\author{
GUNVOR ANDERSSON
}

\section{Inledning}

Den här artikeln har tillkommit i syfte att ge återblickar och reflektera över mitt forskningsfält. När jag med några få nyckelord ska definiera mitt forskningsfält brukar orden "utsatta barn och familjer" och "social barnavård" ingå. Begreppet utsatt är ett vardagligt och oprecist begrepp, som kan rymma olika betingelser. I kopplingen till social barnavård är det avsett att föra tankarna till barn och familjer som lever under socialt utsatta betingelser. Sådana betingelser står i förhållande till normativa föreställningar om vad som är normalt eller vanligt, som de flesta har det, eller hur barn har rätt att ha det eller tonåringar bör bete sig. Användningen av begreppet kan verka stigmatiserande för dem som tillskrivs utsattheten eller definieras som en socialt utsatt grupp. Ändå använder jag begreppet (jfr Andersson \& Sallnäs 2012; Andersson \& Swärd 2008). Det riktar uppmärksamhet på familjeförhållanden som vanligen

Gunvor Andersson, professor emerita, Socialhögskolan, Lunds universitet. inte får utrymme i familjeforskningen, trots dess betoning på senmodernitetens eller postmodernitetens ökade variation i familjeformer och ökade tolerans för olika sätt att leva familjeliv. Begreppet sätter också fokus på levnadsförhållanden för barn som vanligen inte får plats i barndomsforskningen, trots dess betoning på variation $i$ barndomar utifrån kontext och vikten av att se barn som individer med viktiga erfarenheter att förmedla utifrån sitt perspektiv.

Begreppet social barnavård står för den verksamhet inom socialtjänsten som har att se till att barn och familjer får den hjälp de behöver, när generell välfärd inte räcker till. Genom ansökan från föräldrar eller anmälan från personer i omgivningen kan barn aktualiseras inom social barnavård, familjesituationen och barnets behov utredas och någon insats göras. Insatser inom familjen, öppenvårdsinsatser, är vanligast även om det inte framgår av barnavårdsforskningen, som har mer att säga om vård av barn utanför hemmet, i familjehem eller på institution. Det är inte ovanligt att låta den sociala barnavården definiera social utsatthet, dvs. den som är klient är per definition 
utsatt på grund av de villkor som leder till klientskapet. Till barnavårdsområdet kan också de barn och familjer räknas som inte uppmärksammas av socialtjänsten men borde göra det utifrån dess yttersta ansvar för barn som far illa. Den sociala barnavårdens försummelser kan förstärka utsattheten både för dem som aldrig kommer in och för dem som är inne i verksamheten. Min användning av begreppet barnavårdsforskning rymmer både utsatthet och social barnavård.

Mycket har förändrats under de fyra decennier som jag har varit engagerad inom barnavårdsfältet. Då räknar jag in att jag i drygt ett decennium var psykolog inom socialtjänsten innan jag blev lärare och forskare vid Socialhögskolan, Lunds universitet. Det har skett förändringar i lagstiftning, i den sociala barnavårdens organisering, i socialt arbete som yrkesverksamhet och forskningsämne, i människors livsvillkor, i barndomens förutsättningar och synen på barn. Det finns också en del som är bestående i den sociala barnavårdens uppgift, i social utsatthet och utanförskapets villkor. För den här artikeln har jag valt ut fyra dilemman som jag för egen del brottats med över tid och som berör socialt arbete både som praktik och forskningsämne. Med dilemman menar jag då att pendla mellan "å ena sidan" och "å andra sidan" eller finna belägg för "både - och" istället för att ha en entydig ståndpunkt. Det gäller här frågan om individuella och strukturella förhållanden, familjen som enhet och barnen som individer, gränssättningen mellan acceptabla och oacceptabla förhållanden samt ljusa och mörka bilder i forskningsrapportering.

\section{Individ och struktur}

När Karolina Widerström 1906 talade på den kongress, som anordnades av Centralförbundet för Socialt Arbete (CSA), kämpade hon för att ingen ogift mor av nöd ska behöva lämna sitt barn ifrån sig. Ogifta mödrar bör bemötas med större mildhet och tredskande fäder "som så ofta håller sig undan, på en gång fegt och övermodigt" bör avkrävas större pliktuppfyllelse. Hon tänkte sig att om staten ger den ogifta modern stöd och en väl ordnad moderskapsförsäkring "vore fosterbarnsfrågan i samma stund så godt som bragt ur världen" (se Andersson 2006, s. 102). Sedan dess har omfattande familjepolitiska satsningar och strukturella förändringar underlättat föräldraskapet, även för ensamstående mödrar. Ändå är ensamstående mödrar överrepresenterade i den sociala barnavården och fosterbarnsfrågan är inte "bragt ur världen".

Det finns en rad dilemman i förhållandet mellan stat, profession och föräldrar och det finns konkurrerande tankefigurer i socialt arbete med barn och familjer (Johansson \& Bäck-Wiklund 2012). Jag ska här uppehålla mig vid ett dilemma mellan makro- och mikroperspektiv som handlar om det moraliskt försvarbara i att ägna sig åt (miss)förhållanden på individ- och familjenivå och social barnavård, när skälen till både missförhållanden och vidmakthållandet av social barnavård står att finna på övergripande nivåer, i misslyckanden med att skapa social och ekonomisk trygghet för alla och jämlikhet i levnadsvillkor. Social barnavård kritiseras för att inte se de strukturer som skapar fattigdom, en fattigdom 
som i sin tur kan leda till svårigheter att ge barnen tillräckligt god omsorg eller acceptabla hemförhållanden. Fokus på individen riskerar skuldbeläggning av dem som inte klarar föräldraskap och rimliga levnadsförhållanden för barnen.

Det finns samvariation mellan fattigdom och ökad risk för att barnen blir aktuella inom social barnavård. Visserligen är social barnavård så mycket mer än samhällsvård (familjehem eller institution), men det finns registerstudier som visar på den ökade risken för att barnen placeras utanför hemmet om familjen är fattig. Om förhållandena är sådana att barnet har en ensamstående mor, som har låg utbildning, högst grundskola, inte har förvärvsarbete (under valt år) och varit beroende av ekonomiskt bistånd tre år i följd, placeras ett av sju barn i åldern 0-6 år i samhällsvård. För barn i motsvarande ålder, som har en mor som är sammanboende, har högskoleutbildning och förvärvsarbete och inget försörjningsstöd, placeras ett av 2000 barn i åldern 0-6 år utanför hemmet (Franzén, Vinnerljung \& Hjern 2008; Social rapport 2006). Samvariationen mellan familjens fattigdom och samhällsvård är inte lika tydlig för tonåringar, eftersom barnens eget beteende då också spelar en roll. En annan analys av nationella registerdata visar att barn med immigrantbakgrund är överrepresenterade i samhällsvård (Vinnerljung, Franzén, Gustafsson \& Johansson 2008). Här har de yngsta barnen utelämnats på grund av osäkra siffror och frågan gäller endast 7-12-åringar och 13-17-åringar och deras första placering utanför hemmet. Sammanfattningsvis framgår att det finns fler barn med immigrantbakgrund i sam- hällsvård men att denna överrepresentation i stort sett försvinner efter justering för fattigdom och andra socioekonomiska kännetecken (som ensamstående mamma, låg utbildning, beroende av ekonomiskt bistånd). Det är med andra ord fattigdomen som är det utslagsgivande.

Det är otvivelaktigt en ökad påfrestning att tillhöra en socioekonomiskt svag grupp, men det innebär inte per definition att barnen far illa. Det kan vara en tröst för fattiga småbarnsfamiljer, med ovanstående kännetecken, att för sex av sju ifrågasätts inte hemmiljön i den meningen att barnen riskerar samhällsvård. Jag vill inte bidra till att förminska betydelsen av fattigdom, även om jag vill lyfta fram att det tillkommer andra bekymmer, när social barnavård kopplas in (se Andersson 2012). Det är den kumulativa effekten av belastningsfaktorer på olika nivåer som gör att det kan bli för mycket att klara av och barnen riskerar att fara illa. Det är inte oväsentligt vad som görs på individ- och familjenivå. Det är betydelsefullt vad professionella gör - eller inte gör - när de möter barn och familjer i utsatta levnadsförhållanden. För barn, som inte kan vänta på ändrade strukturella förhållanden, kan förbättringar i deras vardagsmiljöer vara livsavgörande.

Jag finner Urie Bronfenbrenners utvecklingsekologiska perspektiv användbart i social barnavård. Han urskiljer fyra olika nivåer som inte är hierarkiskt ordnade utan omsluter varandra (som ryska dockor) och tydliggör att barnet är beroende av såväl mikronivåns närmiljöer som omslutande meso-, exo- och makronivåer (se Andersson 2002/2013). Med tanke på interaktionen mellan nivåer kan arbete på varje nivå 
underlätta för de berörda, bidra med skyddande betingelser och minskad belastning på dem som befinner sig i de svagaste positionerna. En förståelse för sammanhangen är en förutsättning för att kunna vidta adekvata åtgärder mot missförhållanden, menar Bronfenbrenner, men det betyder inte att varje enskild socialarbetare måste arbeta på alla nivåer samtidigt. Man kan ha ett avgränsat fokus i det sociala arbetet med personer som brottas med sociala problem, utan att för den skull ha en snäv syn på problemens orsaker. Han påpekar också risken med att vetenskapen i så hög grad präglas av medelvärden och generella mönster att individuell variation inte uppmärksammas. Det gäller å ena sidan att inte låta fokus på individen skymma kontexten men å andra sidan att inte låta fokus på kontexten skymma individen i utveckling. Ett annat sätt att klara ut dilemmat individ - struktur formulerar Kjersti Ericsson (1997): "På den ene sida må vi lytte mer nedover. till stemmene fra barn som strever med livene sine. På den andre sida må vi heve våre egne stemmer mer oppover. mot dem som styrer det samfunnet disse livene skal leves i."

\section{Föräldrar och barn}

Även om vi bara ser till de senaste fyra decennierna har balansgången sett olika ut mellan att å ena sidan se barnet som en del av familjen och beroende av föräldrars omsorg och å andra sidan som egen individ med egna rättigheter. På 1970- och 1980talet var det en strävan att få in en familjeorientering i socialt arbete, öka det förebyggande arbetet och stödet till familjen samt att i samhällsvården verka för bibehållen kontakt mellan föräldrar och barn och ha återförening som mål. På 1990- och 2000talet kom en ökad betoning på barnet som individ. Barndomssociologin formulerade "ett nytt paradigm" i synen på barnet som kompetent aktör, barnkonventionen betonade barnets rättigheter och socialt arbete fick lagstadgad uppgift att lyssna på barn, ta del av deras perspektiv och göra dem delaktiga i beslut (se t.ex. Rasmusson 2011). Vanligtvis är det inte särskilt motsägelsefullt att säga att ett barn både är beroende av sin familj och har rätt att betraktas som egen individ. Men det händer att barnet som individ inte far väl i sin familj, t.ex. när föräldrar brister i omsorgsförmåga på grund av allvarligt missbruk, psykisk sjukdom, utvecklingsstörning/intellektuell funktionsnedsättning eller förekomst av hot och våld, misshandel och övergrepp i familjen. Då blir social barnavård den samhällsinstans som har det yttersta ansvaret för att göra något som tillgodoser familjens behov av stöd och barnens behov av skydd. Olika länder lägger olika betoning på "family support" och "child protection" i sitt barnavårdssystem (se t.ex. Andersson \& Sallnäs 2012; Freymond \& Cameron 2006). Det kan uppstå en motsättning mellan å ena sidan familjen som enhet och å andra sidan barnet som individ. Det förblir ett dilemma vare sig vi lägger tyngdpunkten på barnets intressen och behov eller på barnets vilja och åsikter (Singer 2012).

I talet om föräldrar döljs att det ofta handlar om en ensamstående mamma. För de barn som blir aktuella i social barnavård är det en överrepresentation av ensamstående mödrar och frånvarande fäder eller 
fäder som bidrar till oacceptabla hemförhållanden på ett sådant sätt att de helst ska hålla sig borta. Det har beskrivits som en "modersfixering" i socialt arbete, som tilldelar mödrar större ansvar för försummelser och tillkortakommanden i omsorgen om barnen men också större tillgång till hjälpoch stödinsatser. Det är ingen orimlig tanke att genom att ge modern en mer central plats än fadern undviks det dilemma, som finns inbyggt $\mathrm{i}$ att barn har två föräldrar. I Maria Bangura Arvidssons (2003) avhandling om ifrågasatta fäder benämns dilemmat "kluvenhet och ambivalens", kluvenhet mellan det traditionella och det moderna föräldraskapet och ambivalens i tolkning av barns bästa i relation till fäder (jfr Bangura Arvidsson 2011). I vårt forskningsprojekt om kontaktperson som umgängesstöd fann vi också en kluvenhet (Andersson \& Bangura Arvidsson 2006 a,b, 2008). Å ena sidan finns generell kunskap om vikten av att barn behåller kontakt med den förälder som de inte bor hos, efter föräldrars skilsmässa. $\AA$ andra sidan kan det vara farligt eller otryggt för yngre barn att träffa sin pappa (som det oftast gäller). Då kan domstol döma till umgänge med kontaktperson, vilket kan ses som en kompromiss mellan barns behov av trygghet och faderns rätt att träffa sitt barn, om han så önskar.

Begreppet barn har en spännvidd på 0-18 år, men tonåringar är betydligt synligare än yngre barn. Det framgår inte minst i vårt forskningsprojekt om pressens bevakning av socialt arbete med utsatta barn (Andersson 2004; Andersson \& Lundström 2007; Lundström 2004). Det är lättare att sätta ord på tonåringars eget beteende än på missförhållanden i hemmiljö. Det fram- går också i Lina Ponnerts (2007) akt- och intervjustudier med socialsekreterare. I ansökan om tvångsvård av yngre barn på grund av hemmiljön fann hon svagare bevisföring än i ansökan om tvångsvård av tonåringar på grund av deras eget socialt nedbrytande beteende. I det förra fallet tänker socialsekreterare på att även lyfta fram föräldrarnas resurser och skriva på ett sådant sätt att fortsatt samarbete med föräldrarna underlättas. Det gäller inte i det senare fallet, eftersom en "hård" argumentation om tonåringars socialt nedbrytande beteende sällan innebär en risk att förlora föräldrarnas fortsatta samarbetsvilja. När det är aktuellt med tvångsvård av tonåringar är föräldrarna oftare med på det och tonåringars egen samarbetsvilja tycks inte vara lika angeläget att värna om (jfr Ponnert 2011). Låt oss betänka att många av dem, som placeras i samhällsvård $i$ tonåren på grund av sitt eget beteende, har upplevt svåra missförhållanden $i$ hemmiljön långt tidigare (59 procent enligt en studie av Sallnäs \& Vinnerljung 2009). Då är det orätt att de inte blir sedda förrän de beter sig illa. Balansen mellan familj och individ ser olika ut för barn i olika åldrar och riskerar att tippa över åt olika håll.

I forskning där barn får komma till tals med sitt perspektiv är tonåringar i klar övervikt. Det är lättare att tala med tonåringar. Det fick vi också motvilligt erkänna i ett forskningsprojekt om barn i hemlöshet (Andersson \& Swärd 2007). Vi hade ambitionen att även tala med förskolebarn, men det var svårt att ställa rätt frågor till dem om boendesituation och vardag. De hade inget att jämföra med och visste inget annat än den situation som var. De talade 
inte svenska och våra frågor via tolk kändes fel och mötte inget gensvar. För att få veta något om yngre barns perspektiv är enstaka intervjuer ingen lämplig väg, där behövs annat tillvägagångssätt och tid att skapa relationer. Även vi fick nöja oss med tonåringars (och deras mammors) röster.

I socialt arbete uppstår dilemman när det gäller hänsyn till föräldrars och barns olika intressen och perspektiv. Ett gott bemötande från socialsekreterare, en respektfull och empatisk hållning, pålitlig information och utrymme för berörda parters delaktighet kan överbrygga motsättningar eller göra dem möjliga att leva med. Det har många barn och föräldrar vittnat om (se t.ex. Andersson 2000, 2002; Andersson \& Rasmusson 2006; Höjer 2007). Man kan också, som Ulf Månsson (1983), se det så att barn- föräldrarelationen tillhör våra existentiella grundfrågor (s. 59-61): Genom att den systematiskt förläggs till gränslandet mellan de sociala myndigheterna och föräldrarna, förskjuts konflikten - intressemotsättningarna - till den professionella grupp, som fått uppdraget att handlägga den. Socialsekreterarna ska se till att den i hög grad samhälleliga konflikten blir omhändertagen på mjukast möjlig sätt och därmed skapar minsta möjliga ångest på makronivå.

\section{Acceptabla och oacceptabla förhållanden}

Socialtjänstlagen innehåller mål, principer och riktlinjer och som ramlag ger den socialarbetare i individ- och familjeinriktat socialt arbete handlingsutrymme (se t.ex.
Svensson, Johnsson \& Laanemets 2008). Här ska jag lyfta fram några dilemman i bedömning av vad som är acceptabelt och oacceptabelt i barns hemförhållanden och beteende.

Ansökningar om stödinsatser och anmälningar om barn som befaras fara illa inkommer till socialtjänsten, som förhandsgranskar dem och tar ställning till om en utredning ska göras. I en förhandsgranskning sorteras de ärenden bort, som inte bedöms behöva utredas. Det är många som sorteras bort i denna första sorteringsprocess, fler ansökningar än anmälningar. Om vi bara ser till anmälningarna kan det vara drygt en tredjedel (Wiklund 2006) eller över hälften (Östberg 2010), men variationen mellan kommuner kan vara större än så (Gegner 2009). Det ställningstagande som görs när anmälan avfärdas utan utredning torde vara att barnets hemförhållanden eller beteende ligger inom normalitetens gräns, eller att det inte finns någon risk för barnet, som skulle motivera utredning. Huruvida den socialsekreterare eller arbetsledare som gör detta ställningstagande upplever något dilemma är inte närmare studerat, men variationen mellan kommuner tyder på individuellt handlingsutrymme.

För de barn och familjer som blir föremål för utredning görs en bedömning av behovet av insatser. Det finns inte nationell statistik att tillgå, men det finns studier som visar på att två tredjedelar får en insats (Östbergs 2010) eller att det kan variera mellan 33 och 85 procent, som i Stockholm, utan att vara relaterat till stadsdelarnas sociala belastning (Sundell, Egelund, Andrée Löfholm \& Kaunitz 2007). I Öst- 
bergs studie framgår att barnets ålder och föräldrarnas bakgrund har betydelse för om utredning följs av insatser, eftersom en större andel av tonåringarna (13-17 år) och familjer med utrikes födda föräldrar får insatser jämfört med andra grupper. När utredning avslutas utan insats är bedömningen att barnets hemförhållanden eller beteende inte är av sådan art att socialtjänstens insatser är adekvata eller av sådan grad att det behövs stöd- och hjälpinsatser i familjen eller placering av barnen utanför hemmet. Denna gränsdragningsproblematik torde utgöra ett dilemma för utredande socialsekreterare, som har att ta hänsyn till såväl barns och föräldrars, som omgivningens och den egna organisationens ibland oförenliga intressen.

I min egen studie av socialt arbete med små barn intervjuade jag alla socialsekreterare i tio kommuner som hade pågående ärenden med barn i 0-3-årsåldern (Andersson 1991). Jag fann att för hälften av de 189 barnen hade socialsekreteraren inte haft sådana betänkligheter om barnets hemförhållanden eller sådan oro att hon övervägt placering utanför hemmet. Hon försattes därför aldrig i "valet och kvalet" eller dilemmat att det fanns förhållanden som talade både för och emot. För den andra hälften bedömdes det finnas sådana brister eller missförhållanden $i$ hemmet att socialsekreteraren övervägt och resonerat med andra om placering av barnen eller också hade barnen redan placerats utanför hemmet. Jag skriver då: "Det är inte orimligt att anta att sociala myndigheters referensramar skapas av de barn, som kommer till deras kännedom. Barnen har en jämn fördelning på mer eller mindre acceptabla hemförhål- landen och någonstans ska gränsen sättas. Här visar det sig att gränsen sätts i mitten" (s. 94; jfr Andersson 2007). Detta handlade enbart om små barn, men det finns tecken på att ärenden med små barn i särskilt hög grad aktualiserar de dilemman, som socialt arbete rymmer. Små barn väcker djupa känslor hos olika parter och det är särskilt svårt att avgöra gränsen för acceptabel föräldraomsorg och godtagbar hemmiljö. Barnen kan inte själva delge sitt perspektiv och det råder olika uppfattningar om vad som är bäst för dem. Det tycks ligga särskilt nära till hands att "vänta och se".

Uppfattningen om vad som är acceptabelt och oacceptabelt är naturligtvis föränderligt över tid och varierar med plats. Det hindrar inte den sociala barnavårdens ansvar att träda in utifrån de värderingar som lagen föreskriver och samhället företräder. Det behöver inte benämnas godtycke även om det finns handlingsutrymme för den sociala barnavårdens aktörer. Om jag går till de barn jag intervjuat, så är uppfattningen genomgående att hemförhållandena var oacceptabla, när de placerades i familjehem. Det var "rätt" att placera dem i familjehem, "alltså som förälder hade jag inte tyckt det var rätt... men jag kan tycka som barn är det rätt, absolut" var vanliga kommentarer (Andersson 2008 s. 115-116). Det var en skyddande faktor i deras liv att få flytta hemifrån och det stod inte i motsats till vikten av att behålla relationer och fortsatt kontakt med föräldrar och andra familjemedlemmar (jfr Andersson 1998b, 2001/2009). Ur barnens synpunkt var det en helt annan fråga att hitta ett bra eller lämpligt familjehem, det är svårare. Det finns smärtsamma belägg för att det före- 
kommer oacceptabla förhållanden i familjehem och på institution (jfr SOU 2011:9). Det kan inte formuleras som ett dilemma mellan acceptabelt och oacceptabelt, eftersom uppgiften där är att nå långt över det acceptabla. Det hindrar inte att det finns gränsdragningsproblem i överväganden om vad som är ett bra familjehem, ett som är tillräckligt bra för det aktuella barnet (Rasmusson \& Regnér 2013).

Det kan vara så, som Tommy Lundström (2012) resonerar, att tillväxten av vetenskapsbaserade bedömningsinstrument och dokumentationssystem är en följd av färre gemensamma och för givet tagna sanningar att luta sig mot i bedömningen av hur det goda föräldraskapet och den goda uppväxten ser ut. Det är min förmodan att dilemmat eller gränsdragningen mellan acceptabla och oacceptabla förhållanden kvarstår, även om socialsekreterare $i$ sin professionella bedömning tar hjälp av utprövade instrument.

\section{Ljusa och mörka bilder}

Barnavårdsforskningen har blivit rikhaltigare under senare decennier. Här ska jag inte ge en allsidig bild utan reflektera över dilemmat att förmedla forskningsresultat på ett sådant sätt att bilden inte blir antingen ljus eller mörk utan nyanserad, när de förhållanden som studeras innehåller både - och. Låt oss hålla i minnet att fler barn (0-18 år) omfattas av öppenvård, dvs. hjälp- och stödinsatser inom familjen, även om det finns mer forskning om barn i familjehem och på institution. Det innebär att kunskap om utsatthetens villkor och den sociala barnavårdens resultat, framför allt återspeglas i eller via samhällsvården. Det är också därifrån jag ska ta exempel, när jag diskuterar ljusa och mörka bilder av hur barn har det eller hur det går för dem. Jag använder bl.a. mina egna två forskningsprojekt om barn i samhällsvård, dvs. en långtidsstudie (med sju uppföljningsstudier) som började med små barn på barnhem (Andersson 1984) och slutade när barnen var unga vuxna i 25-30-årsåldern (Andersson 2008 a,b, 2009) samt en studie med 10-åringar i pågående familjehemsvård (se t.ex. Andersson 1998a,b, 2001/2009).

Likartade forskningsresultat kan tolkas som bra eller dåliga, ge en ljusare eller mörkare bild av aktuella förhållanden. I flera sammanhang har mina forskningsresultat bedömts som mer positiva än vad som framkommit i betydligt mer omfattande akt- och registerstudier om barn $\mathrm{i}$ samhällsvård, där t.ex. låg utbildning, sammanbrott i placeringar och återplaceringar efter återgång till hemmet är framträdande (Vinnerljung 2006; Vinnerljung, Sallnäs \& Kyhle Westermark 2001; Vinnerljung, Öman \& Gunnarson 2004). Om jag använder samma mått och räknar procentfördelning på de 26 barn som jag har följt under hela deras barndom är resultatet förvånansvärt likartat. Hur kan det komma sig att den ena bilden uppfattas som mörkare och den andra som ljusare? Möjligen beror det på att mina studier till stor del bygger på intervjuer. Där framgår t.ex. att det finns nyanser i innebörden av sammanbrott och återplacering. Även om instabilitet $\mathrm{i}$ vården är bekymmersam ur samhällets synpunkt, kan det ur ett enskilt barns synpunkt innebära önskvärt byte av familjehem eller 
önskvärd återplacering i redan känt familjehem. Det finns med andra ord även i ett negativt utfall som instabilitet ett "å ena sidan" men "å andra sidan". Akt- och registerstudier kan med fördel kombineras med intervjustudier för att få grepp om variationen inom gruppen. Det är inte entydigt vad som är bra och dåligt på individnivå.

Hur dåligt eller bra ett utfall är beror på jämförelsegrupp. Jämfört med andra barn är barn med erfarenhet av samhällsvård förlorare. Hur illa det är beror delvis på hur jämförelser presenteras, åtminstone om jag utgår från reaktioner jag mött. Låt mig ta ett exempel: En registerstudie visar att risken för självmordsförsök och psykiatrisk vård (med sjukhusinläggning) var 4-5 gånger högre för 13-17-åringar med erfarenhet av samhällsvård jämfört med andra i samma ålder, överrisker som kvarstod i åldern 19-27 år (Vinnerljung, Hjern \& Lindblad 2006). Det är upprörande dåliga resultat (höga oddskvoter). De blir inte lika upprörande när det visar sig betyda att 1,67 procent av tonåringar med erfarenhet av lång tid i vård och 1,54 procent av tonåringar med erfarenhet av kort tid $i$ vård hade gjort självmordsförsök mot 0,38 procent i motsvarande åldersgrupp i befolkningen i stort. När all psykiatrisk vård (med sjukhusinläggning) räknades så gällde det 3,05 procent av dem som hade lång tid och 2,19 procent av dem som har kort tid $i$ vård mot 0,41 procent av 13-17-åringar i befolkningen i stort. När jag berättar om de två eller tre barn av de 26 i min långtidsstudie, som har gjort självmordsförsök eller varit inlagda på sjukhus för psykiatrisk vård, så uppfattas de som undantag och inte som en större andel än i nämnda registerstudier.
För dem som inte läser forskningsresultat ordentligt kan risker och missförhållanden antingen övervärderas eller undervärderas.

I barndomsforskningen har fokus satts på barndomen här och nu, barnet $\mathrm{i}$ varande (being) har uppvärderats i relation till barnet $\mathrm{i}$ vardande (becoming). På samma sätt kan barnavårdsforskningen fokusera på hur barn har det i vardagen i familjehem och på institution alternativt vad samhällsvården leder till i senare social anpassning. Det var i min studie om 10-åringar i pågående familjehemsvård som jag på allvar fokuserade på hur barnen har det i vardagen - även ur eget perspektiv. Jag intervjuade dem vid tre tillfällen med några veckors mellanrum (se Andersson 1998a). De fick bl.a. reflektera över vad som var annorlunda med att bo i familjehem och ge exempel på skillnader. De flesta tänkte på skillnader jämfört med hur andra barn har det och uppfattade ingen skillnad jämfört hur barn "normalt" har det, det är som att bo i en "vanlig" familj. För dem som hade tydliga minnen hemifrån och jämförde med "hemma", var jämförelsen till familjehemmets fördel. De kände sig tryggare och fick tillgång till fler resurser, som hjälp med läxor, tillgång till dator, de blev skjutsade till ridlektioner och fotbollsmatcher och fick åka på en eller annan semesterresa (Andersson 2001/2009). Det är också resurser i vardagslivet som är i fokus i det större forskningsprojektet "Välfärd i samhällsvården?" (Sallnäs, Wiklund \& Lagerlöf 2010; Lagerlöf 2012). Tonåringar i familjehem och på institution (Hem för Vård och Boende) fick besvara samma frågor som motsvarande åldrar i Barn-ULF, SCB:s levnadsnivåundersökningar. Det visade sig att 
barn i familjehem inte skiljer sig markant från jämförelsepopulationen vad gäller ekonomiska och materiella resurser. Vad gäller de flesta teman inom välfärdsdimensionerna kamratrelationer, skola och fritid låg barn i familjehem betydligt närmre jämförelsegruppen än barn på institution. Det finns med andra ord skillnader inom samhällsvården och i vardagen är bilden av familjehemsvård ljusare än bilden av institutionsvård. Det är rimligt att tillmäta nuet betydelse och se till att vardagen är så bra som möjligt, även om det inte garanterar att det sen "går bra" för barnen, eller lika bra som för andra barn.

Det finns ett dilemma i var tyngdpunken ska läggas i förklaring av forskningsresultat. A ena sidan kan tyngdpunkten läggas på samhällsvården som inte förmår kompensera barnen för tidigare umbäranden i hemmet och ge villkor för utveckling och hälsa i nivå med andra barns. Å andra sidan kan hemförhållanden ha präglat barnen på ett svårartat sätt och gjort dem till förlorare redan innan de kom i samhällsvård. Rimligtvis handlar det om bådadera. Det finns en interaktion mellan tidigare och senare erfarenheter. I mina tidigare nämnda studier har jag intresserat mig för barns relationer till familj och fosterfamilj och förhållandet mellan respektive familjer. Jag visar ljusa bilder av bärkraftiga relationer men ger också exempel på motsatsen (se t.ex. Andersson 1995, 2009). Det som jag upplevt som ett dilemma eller en tvekan är att skriva om barns mörka bilder av hur illa de har farit hemma, vad de har utsatts för och hur stor besvikelse de kan känna, särskilt när de ser tillbaka. Det är ett dilemma att på ett "rättvisande" sätt lyfta fram barns röst eller vad de förmedlar på annat sätt utan att låta det drabba deras föräldrar eller ensamstående mamma, som redan har en tung börda och själv är i en utsatt position. Det är lättare att förmedla mörka bilder av hur illa de kan ha farit i samhällsvård. Men det är inte ovanligt att barn gör egna jämförelser som innebär att de är nöjda med sitt familjehem. Nöjdhet är ett utfallsmått att räkna med och i detta mått spelar relationer en avgörande roll (Andersson 1998b, 2002, 2008b, 2009). Nöjdhet är också ett mått som Tommy Lundström och Marie Sallnäs (2013) resonerar om utifrån att det både $\mathrm{i}$ internationella studier och i deras egen forskning (projekt "Välfärd i samhällsvården?') framkommit att de allra flesta barn är nöjda med sin pågående placering i familjehem, fler än som är nöjda med sin institutionsplacering (HVB). "Det är också påtagligt hur barnen håller fram mer grundläggande relationella aspekter av att personal och familjehemsföräldrar är snälla, att man blir sedd och väl behandlad" (s. 47). Nöjdhet och relationella aspekter har ett egenvärde, även om det är ett subjektivt mått och härrör ur barns eget perspektiv.

Det kan inte ses som ett dilemma i vad mån forskning och praktiskt socialt arbete ska inriktas på barns relationer och nöjdhet eller på barns uppförande och sociala anpassning. Bådadera ingår rimligtvis i en nyanserad bild av en komplex verklighet. Istället vill jag peka på ett dilemma i fördelningen mellan ljusa och mörka bilder. $\AA$ ena sidan är det en samhällsambition att barn i samhällsvård ska ha samma villkor och utvecklingsbetingelser som andra barn. För att nå dit kan det vara ändamåls- 
enligt att visa på missförhållanden, betona det mörka, det som inte är tillräckligt bra. $\AA$ andra sidan är det i berörda barns och familjers intresse att få veta att det finns olika mått och både ljusa och mörka bilder, att alla inte drabbas lika eller har samma uppfattning, att det varierar och att det finns hopp. Hoppet kan i sig utgöra en förändringspotential. Det kan formuleras som ett dilemma hur en kritiskt granskande forskare ska betona missförhållanden i förhållande till godartade förhållanden, men det ska inte förglömmas att ett närmare studium av godartade förhållanden kan bidra till att underlätta färdriktningen för förbättringsarbete.

\section{Avslutande tankar}

Inom social barnavård finns många aspekter som inte är belysta och många frågor som forskare ännu inte har ägnat sig åt. Det finns problem som forskare väljer bort att studera, därför att de är svåråtkomliga med gängse forskningsmetoder eller tidsödande att få grepp om eller inte ligger i linje med det som det finns samhällsintresse för vid vald tidpunkt. Det finns t.ex. mer forskning om social barnavård som institution än om dess innebörd för barn och familjer, mer forskning om den sociala barnavårdens insatser än om utsatta levnadsvillkor, mer forskning om samhällsvård än om ansökningar om hjälp och stöd.

I den här artikeln har jag valt ut några dilemman, som jag uppfattar som bestående över tid. Det hindrar inte att det finns andra angelägna frågor som kan formuleras som dilemman, t.ex. mödrars närvaro och fäders frånvaro. Det ligger nära till hands att se social barnavård som en av de institutioner i samhället som både återspeglar och återskapar genussystemet, dvs. de mekanismer som upprätthåller ett ojämlikt samhälle (se Ulmanen \& Andersson 2006; jfr Lundström \& Sallnäs 2003). I kontrast till återkommande uppgifter om ensamstående mödrars överrepresentation har barnavårdforskningen ingenting att säga om fädernas situation på arbetsmarknaden, deras beroende av ekonomiskt bistånd, deras utbildningsnivå, deras användning av psykiatrisk vård, missbruksvård eller kriminalvård, inte heller om deras bidrag till att underlätta eller försvåra för de barn som bor med sin ensamstående mamma. Både social praktik och forskning är "modersfixerad" på ett mer påtagligt sätt än det omgivande samhället.

Jag har uppehållit mig vid några mig näraliggande dilemman. Det hindrar inte att det finns andra dilemman som socialarbetare kan känna av i mötet med barn och familjer, t.ex. att ha kunskap om bemötandets betydelse och vikten av tillit och kontinuitet i det sociala arbetet och ändå medverka till dess motsats. Som psykolog och verksam inom socialt arbete vill jag inte se en motsättning mellan psykologiskt perspektiv och vikten av att förändra sociala villkor. Jag har burit med mig en formulering av Bengt Börjeson (1984) om att psykologiska frågor ofta är inflätade i sociala komplikationer men att socialarbetare har olika undvikande- och förnekandelösningar på detta dilemma, som (i förkortning) innebär: "Det professionella arbetet innebär alltid att jag måste lämna människor i sticket till följd av tidsbrist"; "Man borde erkänna och 
arbeta med människors genuina svårigheter, men som arbetsplatsen är organiserad går det inte"; "Jag har inga kunskaper att gå djupare, om jag är socialarbetare ska jag inte vara psykolog". Detta undvikande av "den osynliga gränsens problematik", att inte gå vidare till de frågor som ligger bortom det aktuella problemet, har inte inneburit att man inom vårdapparaten istället inriktat sig på att förändra de sociala villkoren till dessa människors bästa. Tvärtom är det så att sociala insatser för förändring kräver psykologisk inlevelse, menar Börjeson. Han formulerar väl att det i detta avseende inte är adekvat att se något dilemma.

Jag låter min avslutande önskan vara att barn i utsatta levnadsförhållanden blir mer synliga i forskning och social praktik och att social barnavård i större utsträckning utformas och uppfattas som hjälp och stöd. Det står inte i motsättning till kritisk reflektion och levande diskussion om de dilemman som finns inbyggda i social barnavård.

\section{Referenser}

Andersson, Gunvor (1984) Små barn på barnhem. Lunds universitet, Psykologiska institutionen/ CWK Gleerup (avhandling).

Andersson, Gunvor (1991) Socialt arbete med små barn. Lund: Studentlitteratur.

Andersson, Gunvor (1995) Barn i samhällsvård. Lund: Studentlitteratur.

Andersson, Gunvor (1998a) Barnintervju som forskningsmetod. Nordisk Psykologi, vol. 50, nr 1, 18-41.

Andersson, Gunvor (1998b) Föräldrakontakt och familjetillhörighet ur fosterbarns perspektiv. Socialvetenskaplig tidskrift, vol. 5, nr 1, 3-23.

Andersson, Gunvor (2000) "Barnen i socialt arbete - en maktlös grupp?" I: Meeeuwisse, A., Sunesson, S. \& Swärd, H. (red.) Socialt arbete. En grundbok. Stockholm: Natur och Kultur (första upplagan).

Andersson, Gunvor (2001/2009) "Barns vardag i familjehem". I Bäck-Wiklund, M. \& Lundström, T. (red.) Barns vardag i det senmoderna samhället. Stockholm: Natur och Kultur (andra upplagan inte omarbetad).

Andersson, Gunvor (2002) "Fosterbarnet, familjen och fosterfamiljen. Intervjuer om familjeformer och relationer." I Söderlind, I. (red.) Uppväxt, familjeformer och barns bästa. Om familjeliv som offentlig angelägenhet och vardaglig praktik. Stockholm: Institutet för framtidsstudier.

Andersson, Gunvor (2002/2013) "Utvecklingsekologi och sociala problem". I Meeuwisse, A. \& Swärd, H. (red.) Perspektiv på sociala problem. Stockholm: Natur och Kultur (andra upplagan omarbetad).

Andersson, Gunvor (2004) "Pressens bild av barns missgärningar". I Blomberg, H., Kroll, C., Lundström, T. \& Swärd, H. (red.) Sociala problem och socialpolitik i massmedier. Lund: Studentlitteratur.

Andersson, Gunvor (2006) "Social barnavård då och nu." I Swärd, H. \& Egerö M-A. (red.) Ligga till last. Fattigdom och utsatthet - socialpolitik och socialt arbete under 100 år. Malmö: Gleerups Utbildning $A B$.

Andersson, Gunvor (2007) "Normalitetens gränser i social barnavård." I Svensson, K. (red.) Normer och normalitet $i$ socialt arbete. Lund: Studentlitteratur.

Andersson, Gunvor (2008a) Utsatt barndom olika vuxenliv. Ett longitudinellt forskningspro- 
jekt ombarn i samhällsvård. Stockholm: Stiftelsen Allmänna Barnhuset, nr 2.

Andersson, Gunvor (2008b) Barndomens placeringar och ungas tillbakablick. Socialvetenskaplig tidskrift, årg. 15, nr 2, 76-96.

Andersson, Gunvor (2009) Foster children: a longitudinal study of placements and family relationships. International Journal of Social Welfare, 18, 13-26.

Andersson, Gunvor (2012) "Barn, fattigdom och social barnavård". I Swärd, H. \& Engelmark, L. (red.) Fattigdom utan gränser. Stockholm: Carlssons Bokförlag.

Andersson, Gunvor \& Bangura Arvidsson, Maria (2006a) Barnet mellan två föräldrar - insatsen kontaktperson i umgängestvister. Stockholm: Stiftelsen Allmänna Barnhuset, nr 2.

Andersson, Gunvor \& Bangura Arvidsson, Maria (2006b) Umgänge till varje pris? Socionomens Forskningssupplement, nr 19, 5-17, i Socionomen, nr 5, del 2.

Andersson, Gunvor \& Bangura Arvidsson, Maria (2008) Contact person as a court-ordered solution in child visitation disputes in Sweden. Child and Family Social Work, 13, 197-206.

Andersson, Gunvor \& Lundström, Tommy (2007) Teenagers as victims in the press. Children \& Society, vol. 21, 175-188.

Andersson, Gunvor \& Rasmusson, Bodil (2006) Fosterbarns perspektiv på socialtjänstens företrädare. Socialmedicinsk tidskrift, årg. 83, häfte 1, 5-15.

Andersson, Gunvor \& Sallnäs, Marie (2012) "Social barnavård och barns utsatthet." I Höjer, I., Sallnäs, M. \& Sjöblom, Y.(red.) När samhället träder in - barn, föräldrar och social barnavård. Lund: Studentlitteratur.

Andersson, Gunvor \& Swärd, Hans (2007) Barn utan hem. Olika perspektiv. Lund: Studentlitteratur.

Andersson, Gunvor \& Swärd, Hans (2008) "Etiska reflektioner". I Meeuwisse, A.Swärs, H., Eliasson-Lappalainen, R \& Jacobsson, K. (red.) Forskningsmetodik för socialvetare. Stockholm: Natur \& Kultur.

Bangura Arvidsson, Maria (2003) Ifrågasatta fäder. Olika bilder av fäder till socialt utsatta barn. Lunds universitet: Socialhögskolan, Lund Dissertations in Social Work 13 (avhandling).

Bangura Arvidsson, Maria (2011) "Föräldraskap i den sociala barnavården." I Andersson, G., Bangura Arvidsson, M., Mattsson, T., Ponnert, L. \& Rasmusson, B. Social barnavård - några utmaningar. Glimtar frän forskning ur olika perspektiv. Lunds universitet: Meddelanden från Socialhögskolan 2011:6.

Börjeson, Bengt (1984) En diskussion om det psykosociala arbetet och dess teoretiska utgångspunkter. Umeå universitet: Institutionen för socialt arbete (stencil).

Ericsson, Kjersti (1997) "Barnevern som samfunnsspeil - hva ser vi i speilet?" Plenarföredrag på Nordiska barnevernskongressen (konferenspaper).

Franzén, Eva, Vinnerljung, Bo \& Hjern, Anders (2008) The epidemiology of out-of-home care for children and youth: A national cohort study. British Journal of Social Work, 38, 10431059 .

Freymond, Nancy \& Cameron, Gary (2006) (eds.) Towards positive systems of child and family welfare. International comparisons of child protection, family service and community caring systems. Toronto: University of Toronto Press.

Gegner, Harald (2009) Förhandsgranskningar $i$ barnavårdsärenden. Lund: FoU Skåne, Skriftserie 2009:5.

Höjer, Ingrid (2007) Föräldrars röster - hur är det att ha sina barn placerade i fosterhem? Stockholm: Stiftelsen Allmänna Barnhuset, nr 2.

Johansson, Helena \& Bäck-Wiklund, Margareta (2012) Att fostra familien - en grundbok om styrning, föräldraskap och socialtjänst. Malmö: Liber.

Lagerlöf, Hélène (2012) Samhällsvård och välfärdsresurser. En studie av skolgång, fritid och kamratrelationer bland unga i familjehem och institutioner. Stockholms universitet: Rapport $\mathrm{i}$ socialt arbete $\mathrm{nr} 137$ (avhandling).

Lundström, Tommy (2004) "Mellan vardag och dramatik. Pressens bevakning av socialt arbete med utsatta barn och unga". I Blomberg, H., 
Kroll, C., Lundström, T. \& Swärd, H. (red.)

Sociala problem och socialpolitik i massmedier.

Lund: Studentlitteratur.

Lundström, Tommy (2012) "Risk och riskbedömningar." I Höjer, I., Sallnäs, M. \& Sjöblom, Y.(red.) När samhället träder in - barn, föräldrar och social barnavård. Lund: Studentlitteratur.

Lundström, Tommy \& Sallnäs, Marie (2003) Klass, kön och etnicitet i den sociala barnavården. Socialvetenskaplig tidskrift, nr 2-3, 193-213.

Lundström, Tommy \& Sallnäs, Marie (2013) Att värdera dygnsvård - hur nöjda är barnen och vilken betydelse har det? Socionomens Forskningssupplement i Socionomen, $\mathrm{nr}$ 1, 40-51.

Månsson, Ulf (1983) "Den svåraste arbetsuppgiften. Arbetet med barn som far illa". I Göransson, I., Månsson, U. \& Sundman, A.K. Socialsekreterarnas arbetsmiljö. Stockholm: Liber Förlag.

Ponnert, Lina (2007) Mellan klient och rättssystem. Tvaingsvård av barn och unga ur socialsekreterares perspektiv. Lunds universitet: Socialhögskolan, Lund Dissertations in Social Work 29 (avhandling).

Ponnert, Lina (2011) "Socialsekreteraren i organisationen." I Andersson, G., Bangura Arvidsson, M., Mattsson, T., Ponnert, L. \& Rasmusson, B. Social barnavård - några utmaningar. Glimtar från forskning ur olika perspektiv. Lunds universitet: Meddelanden från Socialhögskolan 2011:6.

Rasmusson, Bodil (2011) "Barnperspektivet och barns delaktighet." I Andersson, G., Bangura Arvidsson, M., Mattsson, T., Ponnert, L. \& Rasmusson, B. Social barnavård - några utmaningar. Glimtar frän forskning ur olika perspektiv. Lunds universitet: Meddelanden från Socialhögskolan 2011:6.

Rasmusson, Bodil \& Regnér, Margareta (2013) Ett utvalt hem till ett utvalt barn. Familjehemsutredningar och socialt arbete i praktiken. Stockholm: Natur \& Kultur.

Sallnäs, Marie \& Vinnerljung, Bo (2009) Samhällsvårdade tonåringar som vuxna - en uppföljande registerstudie. Forskningssupplement, nr
25, i Socionomen, nr 5, 30-43.

Sallnäs, Marie, Wiklund, Stefan \& Lagerlöf, Hélène (2010) Social barnavård ur ett välfärdsperspektiv. Ekonomiska och materiella resurser, psykisk hälsa och tillgång till stöd för ungdomar i familjehem och på institutioner. Socialvetenskaplig tidskrift, årg. 17, nr 1, 5-27.

Singer, Anna (2012) "Alla talar om barns rätt." I Rätt, social utsatthet och samhälleligt ansvar. Festskrift till Anna Hollander. Stockholm: Norstedts Juridik.

Social rapport 2006. Stockholm: Socialstyrelsen.

SOU 2011:9 Barnen som samhället svek - àtgärder med anledning av övergrepp och allvarliga försummelser i samhällsvården. Stockholm: Socialdepartementet, Statens Offentliga Utredningar.

Sundell, Knut, Egelund, Tine, Andrée Löfholm, Cecilia \& Kaunitz, Catrine (2007) Barnavårdsutredningar. En kunskapsöversikt. Stockholm: IMS och Gothia Förlag.

Svensson, Kerstin, Johnsson, Eva \& Laanemets, Leili (2008) Handlingsutrymme. Utmaningar $i$ socialt arbete. Stockholm: Natur och Kultur.

Ulmanen, Petra \& Andersson, Gunvor (2006) Svensk social barnavård ur ett könsperspektiv 1993-2003. En litteraturgenomgaing. Stockholm: Statens institutionsstyrelse SiS, nr 1.

Wiklund, Stefan (2006) Den kommunala barnavården - om anmälningar, organisation och utfall. Stockholms universitet: Institutionen för socialt arbete/Socialhögskolan (avhandling).

Vinnerljung, Bo (2006) Fosterbarn som unga - en översikt av resultat från några nationella registerstudier. Socialmedicinsk tidskrift, årg. 83, 1, 23-35.

Vinnerljung, Bo, Franzén, Eva, Gustafsson, Björn \& Johansson, Ing-Marie (2008) Out-of-home care among immigrant children in Sweden: a national cohort study. International Journal of Social Welfare, 17, 301-311.

Vinnerljung, Bo, Hjern, Anders \& Lindblad, Frank (2006) Suicide attempts and severe psychiatric morbidity among former child welfare clients - a national cohort study. Journal of Child Psychology and Psychiatry, vol. 16, 163-202. 
Vinnerljung, Bo, Sallnäs, Marie \& Kyhle Westermark, Pia (2001) Sammanbrott vid tonårsplaceringar - om ungdomar i fosterhem och på institution. Stockholm: Socialstyrelsen, CUS.

Vinnerljung, Bo, Öman, Maria \& Gunnarson, Thomas (2004) Återplacering av barn i dygns- vård (I) - hur vanligt är det? Socialvetenskaplig tidskrift, vol. 11, nr 1, 54-73.

Östberg, Francesca (2010) Bedömningar och beslut. Från anmälan till insats $i$ den sociala barnavairden. Stockholms universitet: Rapport i socialt arbete, $\mathrm{nr} 134$ (avhandling).

Gunvor Andersson: Reflektioner om dilemman i social barnavård 